\title{
Installation Schemes for Downconductors at Airport Traffic Control Towers (ATCT)
}

\author{
Loren Carvajal \\ Federal Aviation Administration \\ Power Services Group, ATO-W/ATC Facilities \\ Washington DC, USA \\ loren.carvajal@faa.gov
}

\author{
Ben Wibisono and Enrique Tenicela \\ Lockheed Martin NISC-III \\ Washington DC, USA \\ ben.ctr.wibisono@faa.gov; enrique.ctr.tenicela@faa.gov
}

\begin{abstract}
This paper focuses on design practices for the effective placement of downconductors to increase the level of direct lightning strike protection of Airport Traffic Control Towers (ATCT) in the United States. The adopted design practice is based on the use of the voltage gradient model as applied to tall towers. A scheme of balanced placement of downconductors for ATCTs is presented along with a simplified PSpice simulation that indicates related performance improvements.
\end{abstract}

Keywords: electric field, convex geometry, lightning protection, balanced configuration

\section{INTRODUCTION}

The Federal Aviation Administration (FAA) has an inventory of approximately 3400 ATCTs in the United States. ATCTs vary in shape, diameter, and height. Older ATCTs and those that are located on small airports are typically less than 100 feet tall, whereas ATCTs at major airports can be more than 300 feet tall. The unique geometry of ATCTs presents challenges in designing a standardized lightning protection scheme that is effective for sustaining continuous air traffic operation across all classes of environments and locations throughout the United States.

Observations indicate that direct lightning strikes to tall structures have a tendency to attach not only to the air terminals placed atop the structures, but also to other zones such as corners and edges. Several studies based on the influence of the electric field on convex geometry have been conducted to determine the higher attractive locations of a structure that is subjected to a direct lightning strike [1]. In such attractive locations, customary techniques for lightning protection must be augmented to intercept lightning and conduct the flow of lightning energy to ground with minimal impedance. Reduced impedance reduces the risk of damage to the surrounding structure as well as to the electronic equipment used for air traffic operation inside the structure.

\section{BACKGROUND}

\section{A. Electric Field Influence on Convex Geometries}

The external electric field distribution between charged clouds and the outer surface of tall convex structures is intensified during thunderstorms. When an external field surrounds the structure, surface charges tend to accumulate at the corners and edges [1][2]. A formation called an "equipotential field envelope" forms around the structure. This envelope forms a set of voltage gradients that influence the mobilization of electrical charges toward the edges of the structure. A higher concentration of voltage gradients will develop at the topmost and outermost sections of the structure where sharp geometries predominate. Thus, charges from the middle and lower ground planes have a great tendency to migrate to corners and sharp edges of the building geometry as shown in Figure 1. These geometrical locations constitute points of vulnerability that must to be protected. The placement of external lightning protection for FAA ATCTs is based on this geometrical approach and field intensification model.

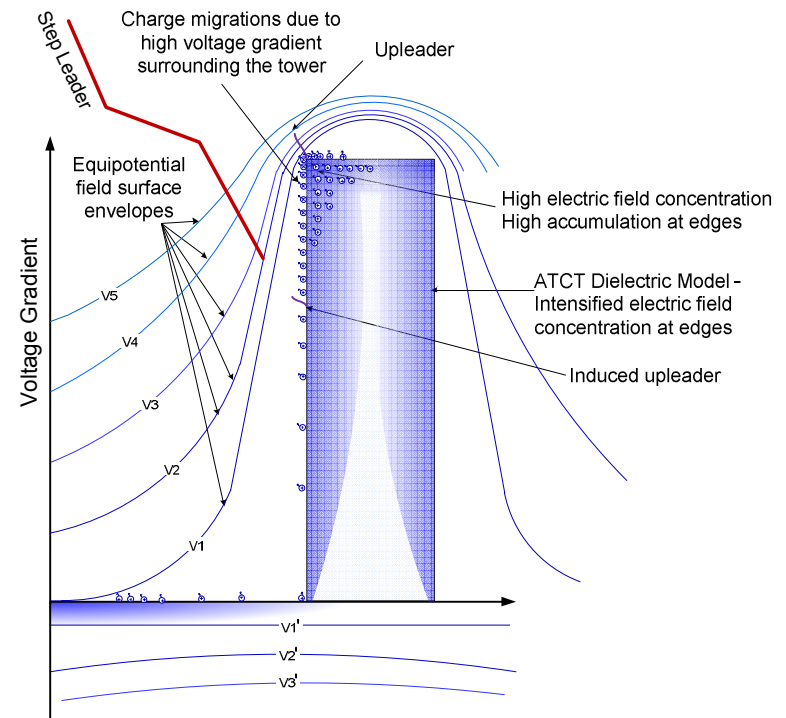

Figure 1. Electric Field Influence on Convex Geometries of an Unprotected Structure 


\section{B. Downconductor Scheme Arrangement}

Protection of ATCTs in the FAA is considered a special case for several reasons:

- The shape of the ATCT is slender and tall (can be more than 300 feet),

- The ATCT's critical function is to control airport traffic operations, requiring the ATCT to stay operational even in adverse weather conditions,

- The ATCT houses both persons and sensitive electronic equipment.

The FAA is not aware of any U.S. commercial (consensus) standard that addresses lightning protection applications for specialized structures and equipment that are in the agency's inventory such as ATCTs, surveillance and weather radar towers, and landing and navigation systems. The FAA publishes a performance standard FAA-STD-019e [3] that addresses not only personnel and building safety, but also equipment performance necessary for carrying out FAA's mission of delivering continuous air traffic operation to the flying public.

In Table I, the authors compare lightning protection schemes that are described in the NFPA 780 [4] for ordinary structures with the requirements in FAA-STD-019e for ATCTs. In addition, a more stringent approach based on structure geometry is presented, and this is compared with the first two methods.

TABLE I. COMPARISON OF VARIOUS LIGHTNING PROTECTION SCHEMES

\begin{tabular}{|c|c|c|c|}
\hline & NFPA 780 & $F A A-S T D-019 e$ & $\begin{array}{c}\text { Geometry-Based } \\
\text { Approach }\end{array}$ \\
\hline $\begin{array}{l}\text { Air terminal } \\
\text { placement }\end{array}$ & $\begin{array}{l}\text { Install strike } \\
\text { termination } \\
\text { devices around } \\
\text { the perimeter of } \\
\text { the roof at } \\
\text { intervals not } \\
\text { exceeding } 20 \mathrm{ft} \\
\text { and within } 2 \mathrm{ft} \text { of } \\
\text { roof corners } \\
(4.8 .1 \text { and } \\
4.8 .1 .1)\end{array}$ & $\begin{array}{l}\text { Install strike } \\
\text { termination } \\
\text { devices around } \\
\text { perimeter of the } \\
\text { roof at intervals } \\
\text { not exceeding } 20 \mathrm{ft} \\
(4.2 .3 .5 .1)\end{array}$ & $\begin{array}{l}\text { Install strike } \\
\text { termination } \\
\text { devices at every } \\
\text { corner of the } \\
\text { ATCT and } \\
\text { around the } \\
\text { perimeter of the } \\
\text { roof at intervals } \\
\text { not exceeding } 20 \\
\mathrm{ft}\end{array}$ \\
\hline $\begin{array}{l}\text { Down } \\
\text { conductor } \\
\text { placement }\end{array}$ & $\begin{array}{l}\text { As widely } \\
\text { separated as } \\
\text { possible (3.9.9.1) }\end{array}$ & $\begin{array}{l}\text { Based on the } \\
\text { building geometry } \\
(4.2 .3 .5 .3)\end{array}$ & $\begin{array}{l}\text { Based on the } \\
\text { building } \\
\text { geometry }\end{array}$ \\
\hline $\begin{array}{l}\text { Number of } \\
\text { down } \\
\text { conductors }\end{array}$ & $\begin{array}{l}\text { At least two } \\
\text { down conductors } \\
\text { must be provided } \\
\text { for any kind of } \\
\text { structure }(4.9 .10)\end{array}$ & $\begin{array}{l}\text { Number of down } \\
\text { conductors is } \\
\text { based on building } \\
\text { height and } \\
\text { perimeter. } \\
\text { Buildings more } \\
\text { than } 100 \mathrm{ft} \text { high } \\
\text { shall have four } \\
\text { down conductors } \\
\text { plus one additional } \\
\text { conductor for each } \\
50 \mathrm{ft} \text { of height or } \\
\text { part thereof } \\
(4.2 .3 .5 .3)\end{array}$ & $\begin{array}{l}\text { Number of down } \\
\text { conductors is } \\
\text { based on building } \\
\text { geometry and } \\
\text { height. At } \\
\text { minimum, install } \\
\text { one down } \\
\text { conductor at each } \\
\text { building corner. } \\
\text { Run down } \\
\text { conductors along } \\
\text { the corner edges } \\
\text { of the building. } \\
\text { Maintain a } \\
\text { geometrically }\end{array}$ \\
\hline
\end{tabular}

\begin{tabular}{|c|c|c|c|}
\hline & NFPA 780 & $F A A-S T D-019 e$ & $\begin{array}{c}\text { Geometry-Based } \\
\text { Approach }\end{array}$ \\
\hline & & & $\begin{array}{l}\text { balanced } \\
\text { configuration in } \\
\text { all cases. }\end{array}$ \\
\hline $\begin{array}{l}\text { Roof-level } \\
\text { potential } \\
\text { equalization }\end{array}$ & $\begin{array}{l}\text { For structures } \\
\text { exceeding } 60 \mathrm{ft} \\
\text { high, all } \\
\text { grounded media } \\
\text { in or on the } \\
\text { structure shall be } \\
\text { interconnected } \\
\text { within } 12 \mathrm{ft} \text { of } \\
\text { the main roof } \\
\text { level }(4.20 .2)\end{array}$ & $\begin{array}{l}\text { A continuous } \\
\text { potential } \\
\text { equalization loop } \\
\text { shall be installed } \\
\text { on the roof within } \\
24 \text { in. of the } \\
\text { periphery of the } \\
\text { structure. All air } \\
\text { terminals and } \\
\text { downconductors } \\
\text { shall be connected } \\
\text { to this loop } \\
(4.2 .3 .5 .2)\end{array}$ & $\begin{array}{l}\text { A continuous } \\
\text { potential } \\
\text { equalization loop } \\
\text { shall be installed } \\
\text { on the roof } \\
\text { within } 24 \text { in. of } \\
\text { the periphery of } \\
\text { the structure. All } \\
\text { air terminals and } \\
\text { downconductors } \\
\text { shall be } \\
\text { connected to this } \\
\text { loop }(4.2 .3 .5 .2)\end{array}$ \\
\hline $\begin{array}{l}\text { Intermediate- } \\
\text { level } \\
\text { potential } \\
\text { equalization }\end{array}$ & $\begin{array}{l}\text { The lightning } \\
\text { protection system } \\
\text { downconductors } \\
\text { and other } \\
\text { grounded media } \\
\text { shall be } \\
\text { interconnected } \\
\text { with a loop } \\
\text { conductor at } \\
\text { intermediate } \\
\text { levels not } \\
\text { exceeding } 60 \mathrm{ft} \\
(4.20 .3 .3)\end{array}$ & $\begin{array}{l}\text { A potential } \\
\text { equalization loop } \\
\text { shall be installed at } \\
\text { intermediate } \\
\text { levels, evenly } \\
\text { spaced no more } \\
\text { than } 60 \mathrm{ft} \text { apart, } \\
\text { measured from the } \\
\text { roof loop. } \\
\text { Additional } \\
\text { horizontal air } \\
\text { terminals shall be } \\
\text { installed at each } \\
\text { corner }(4.2 .3 .5 .2)\end{array}$ & $\begin{array}{l}\text { A potential } \\
\text { equalization loop } \\
\text { shall be installed } \\
\text { at intermediate } \\
\text { levels, evenly } \\
\text { spaced no more } \\
\text { than } 60 \mathrm{ft} \text { apart, } \\
\text { measured from } \\
\text { the roof loop. } \\
\text { Additional } \\
\text { horizontal air } \\
\text { terminals shall be } \\
\text { installed at each } \\
\text { corner }(4.2 .3 .5 .2)\end{array}$ \\
\hline $\begin{array}{l}\text { Ground-level } \\
\text { potential } \\
\text { equalization }\end{array}$ & $\begin{array}{l}\text { For structures } \\
\text { exceeding } 60 \mathrm{ft} \text { in } \\
\text { height, the } \\
\text { interconnection } \\
\text { of the lightning } \\
\text { protection system } \\
\text { grounding } \\
\text { electrodes and } \\
\text { other grounded } \\
\text { media shall be in } \\
\text { the form of a } \\
\text { ground loop } \\
\text { conductor } \\
(4.20 .1 .2)\end{array}$ & $\begin{array}{l}\text { An earth electrode } \\
\text { system (EES) shall } \\
\text { be installed at each } \\
\text { facility. The } \\
\text { purpose of the } \\
\text { EES is to provide a } \\
\text { low resistance to } \\
\text { earth for lightning } \\
\text { discharges, } \\
\text { electrical and } \\
\text { electronic } \\
\text { equipment } \\
\text { grounding, and } \\
\text { surge and transient } \\
\text { protection. The } \\
\text { EES shall be } \\
\text { capable of } \\
\text { dissipating within } \\
\text { the earth the } \\
\text { energy of direct } \\
\text { lightning strikes } \\
\text { with no ensuing } \\
\text { degradation to } \\
\text { itself (4.2.4.1) } \\
\text { The EES shall } \\
\text { normally consist of } \\
\text { driven ground } \\
\text { rods, buried } \\
\text { interconnecting } \\
\text { conductors, and } \\
\text { connections to } \\
\text { underground } \\
\text { metallic pipes (not } \\
\text { including gas } \\
\text { lines), and tanks } \\
\text { (4.2.4.3) }\end{array}$ & $\begin{array}{l}\text { An EES shall be } \\
\text { installed at each } \\
\text { facility. The } \\
\text { purpose of the } \\
\text { EES is to provide } \\
\text { a low resistance } \\
\text { to earth for } \\
\text { lightning } \\
\text { discharges, } \\
\text { electrical and } \\
\text { electronic } \\
\text { equipment } \\
\text { grounding, and } \\
\text { surge and } \\
\text { transient } \\
\text { protection. The } \\
\text { EES shall be } \\
\text { capable of } \\
\text { dissipating } \\
\text { within the earth } \\
\text { the energy of } \\
\text { direct lightning } \\
\text { strikes with no } \\
\text { ensuing } \\
\text { degradation to } \\
\text { itself ( } 4.2 .4 .1 \text { ) } \\
\text { The EES shall } \\
\text { normally consist } \\
\text { of driven ground } \\
\text { rods, buried } \\
\text { interconnecting } \\
\text { conductors, and } \\
\text { connections to } \\
\text { underground } \\
\text { metallic pipes } \\
\text { (not including } \\
\text { gas lines), and } \\
\text { tanks ( } 4.2 .4 .3 \text { ) }\end{array}$ \\
\hline
\end{tabular}


To see how the three different schemes above are implemented for ATCT designs, let us consider two octagonal geometry shaped ATCTs, the first one with height $h=170$ feet and the second with $\mathrm{h}=300$ feet. The lightning protection designs based on the above schemes are presented in the graphical format below (Figures 2 and 3).

Figure 2 shows that applying NFPA 780 to the $170-\mathrm{ft}$-tall ATCT will leave many building corners unprotected, exposing these areas to possible side strikes. Applying FAA-STD-019e yields better results, leaving only two of eight building corners unprotected. The proposed geometry-based approach ensures all building corners are protected by downconductors.

All three schemes add intermediate-level equalization rings spaced evenly along the height of the ATCT. In addition, FAA-STD-019e and the geometry-based approach call for horizontally mounted air terminals that serve as attachment points for side-strike lightning, creating a better zone of protection on the sides of the ATCT (Figure 3).

For the $300 \mathrm{ft}$ ATCT, the number of downconductors does not change after applying NFPA 780 (Figure 4). FAA-STD019e requires additional downconductors to be installed for taller ATCTs, which in this particular case yields a total of eight down conductors, protecting each corner of the building. The geometry-based approach is the same. It will be seen that the geometry-based approach ensures protection at each building corner location regardless of the height of the structure.

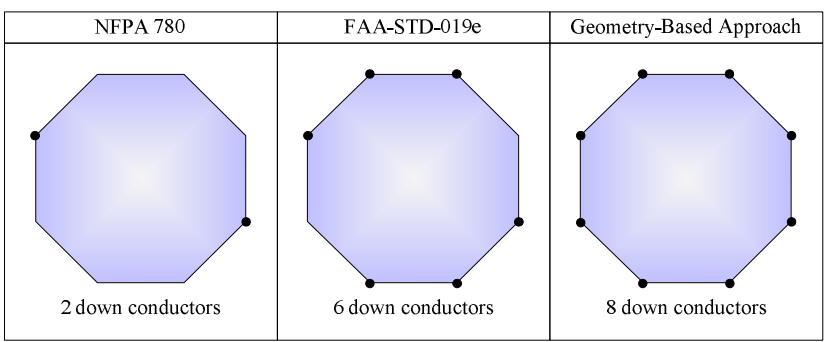

Figure 2. Placement and Number of Downconductors (Top View) for Octagon ATCT Geometry, $170 \mathrm{ft}$ in Height

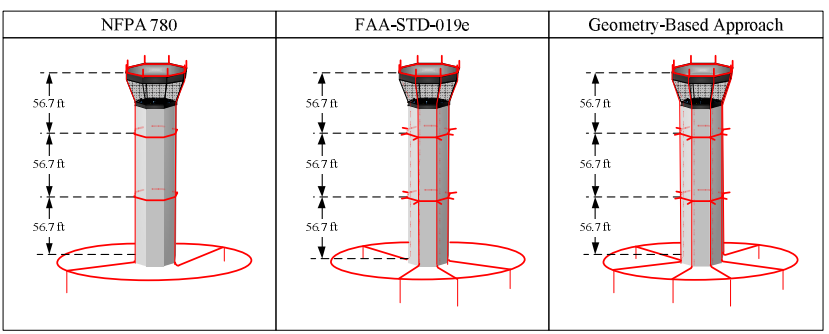

Figure 3. Placement of Equalization Rings for Octagon ATCT $170 \mathrm{ft}$ in Height

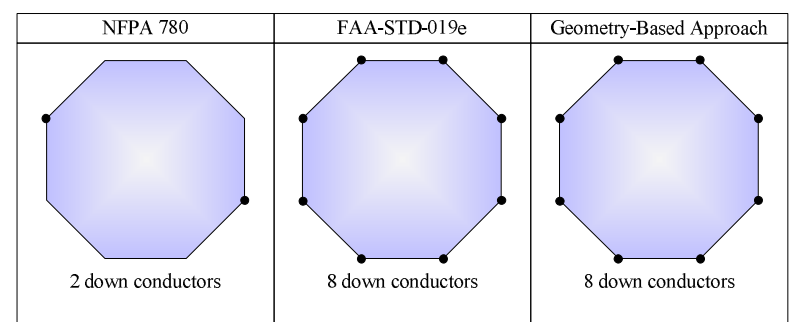

Figure 4. Placement and Number of Downconductors (Top View) for Octagon ATCT Geometry, $300 \mathrm{ft}$ in Height

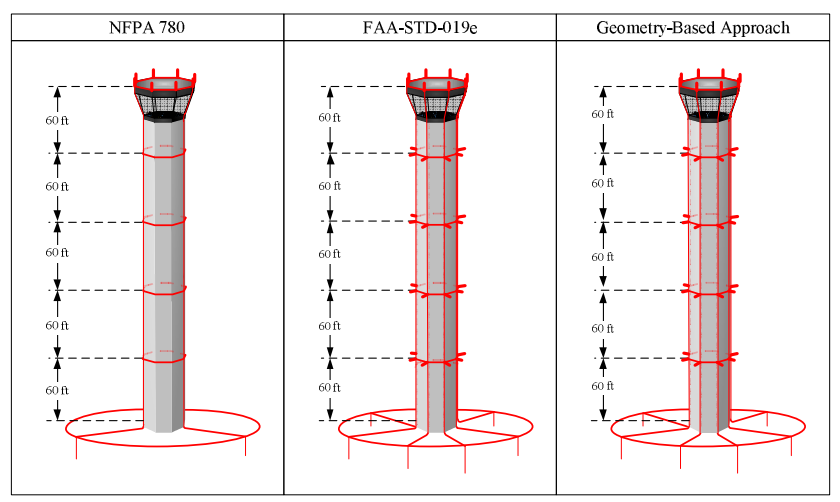

Figure 5. Placement of Equalization Rings for Octagon ATCT $300 \mathrm{ft}$ in Height

In Figure 5, all three schemes result in the addition of intermediate level equalization rings spaced evenly along the height of the $300 \mathrm{ft}$ ATCT. As with the 170-ft octagon ATCT, FAA-STD-019e and the geometry-based approach schemes call for horizontally mounted air terminals that serve as attachment points for side-strike lightning, creating a better zone of protection along the sides of the ATCT.

\section{OBSERVATIONS}

NFPA 780 does not call for additional downconductors as the height of the structure increases, requiring only two downconductors for both the $170 \mathrm{ft}$ and the $300 \mathrm{ft}$ ATCTs. The FAA-STD-019e scheme calls for additional downconductors as the height of the structure increases. The geometry-based approach focuses on running the downconductors at every building corner where the electric field influence is the strongest.

All three schemes call for the installation of equalization rings at all levels. One difference is that FAA-STD-019e and the geometry-based approach call for horizontally mounted air terminals to create a zone of protection along the vertical sides of the ATCT.

The next section analyzes the effect of increasing the number of downconductors for a particular building height as well as the benefit of installing equalization rings. 


\section{ANALYSIS USING PSPICE}

The PSpice program will be used to demonstrate the following:

1. To show the effect of increasing the number of downconductors. As the number of downconductors increases, the overall system impedance decreases. Hence the total net voltage at any particular point in the system is reduced.

2. To show the benefits of installing equalization rings. Equalization rings reduce the voltage difference at each particular height of the structure, creating symmetrical charge balance in the structure.

For the first simulation, corresponding to point 1 above, a hexagon ATCT $300 \mathrm{ft}$ in height with $30 \mathrm{ft}$ per side is used (Figure 6). Three-hundred-foot-long downconductors are run from the top of the ATCT to a perfectly conducting ground. The number of downconductors will be varied to show the effect of increasing the number of downconductors. For this simulation, there are no intermediate equalization rings included. The lightning downconductors are represented by a series of distributed inductances of $1 \mu \mathrm{H} / \mathrm{m}$ and a series of distributed resistances of $0.005 \Omega / \mathrm{m}$. Each leg of the downconductor is modeled as a simple vertical set of paired inductor-resistors in series to represent two symmetrical vertical sections of $150 \mathrm{ft}$ each. They are interconnected at the top of the ATCT to a single roof equalization ring, which is illustrated using the same distributed inductor-resistor pair, each pair representing a $30-\mathrm{ft}$ section of roof conductor. The ATCT model is then connected to a $40 \mathrm{kA}$ lightning impulse generator using a Marx Generator circuit model (Figure 7) [5]. The voltage response on this ATCT model is measured on the opposite site of the impulse injection point.

The PSpice simulation shows that the maximum peak voltage at the measurement point decreases as the number of downconductors increases (Figure 8). More downconductors adds more parallel paths between the top of the structure and ground, creating an overall lower impedance path for lightning energy to flow to ground. In this simulation, increasing the number of downconductors from two to six yields approximately $30 \%$ in performance improvement.

For the second simulation (corresponding to point 2 above), the same model is used (six downconductors) but now with the beneficial addition of an equalization ring. At first, for comparison purposes, voltage measurements are taken with the ring omitted, at the middle part of the downconductors (Figures 9 and 10). The maximum voltage difference at the midpoint of the ATCT is measured as $104 \mathrm{kV}$.
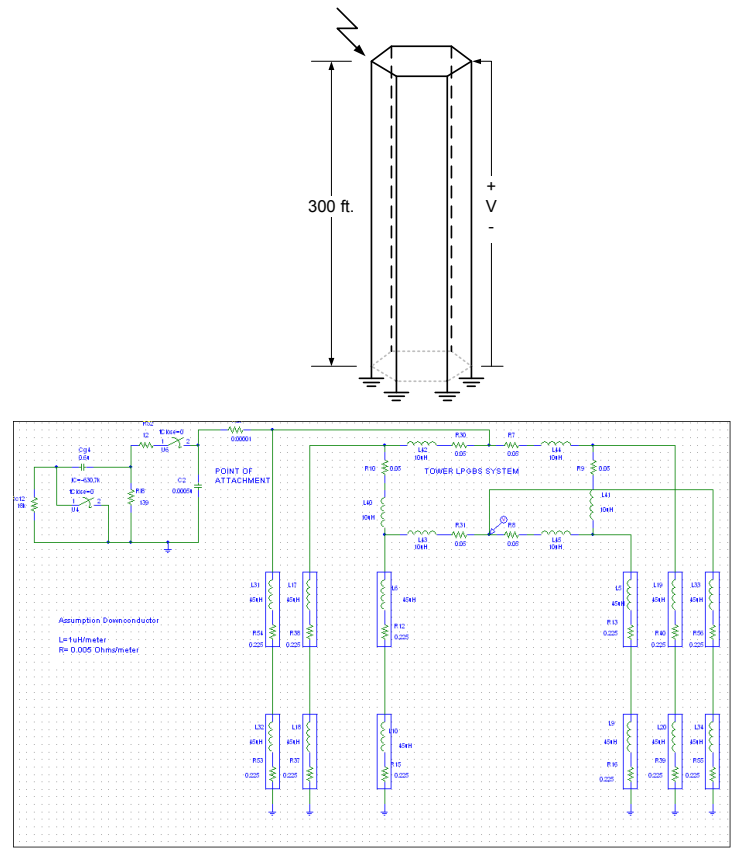

Figure 6. PSpice Lightning Protection Model for Hexagon ATCT $300 \mathrm{ft}$ in Height

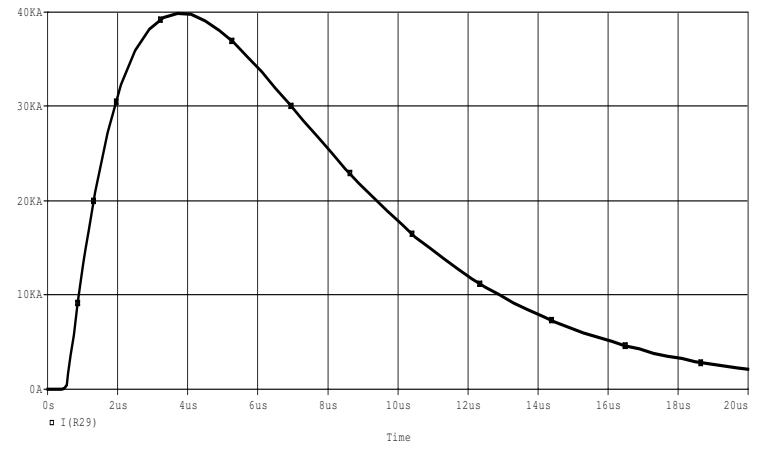

Figure 7. 40kA lightning Impulse Waveform from Marx Generator

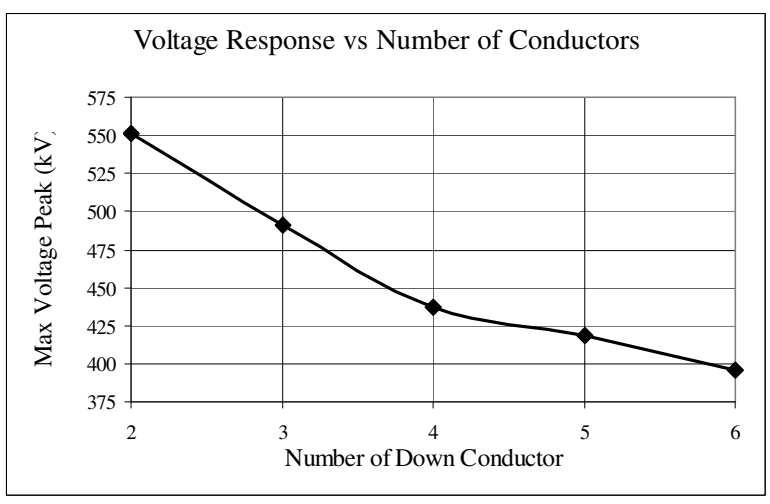

Figure 8. During Simulated Lightning Impulse, the Maximum Peak Voltage Decreases as the Number of Downconductors Increases 

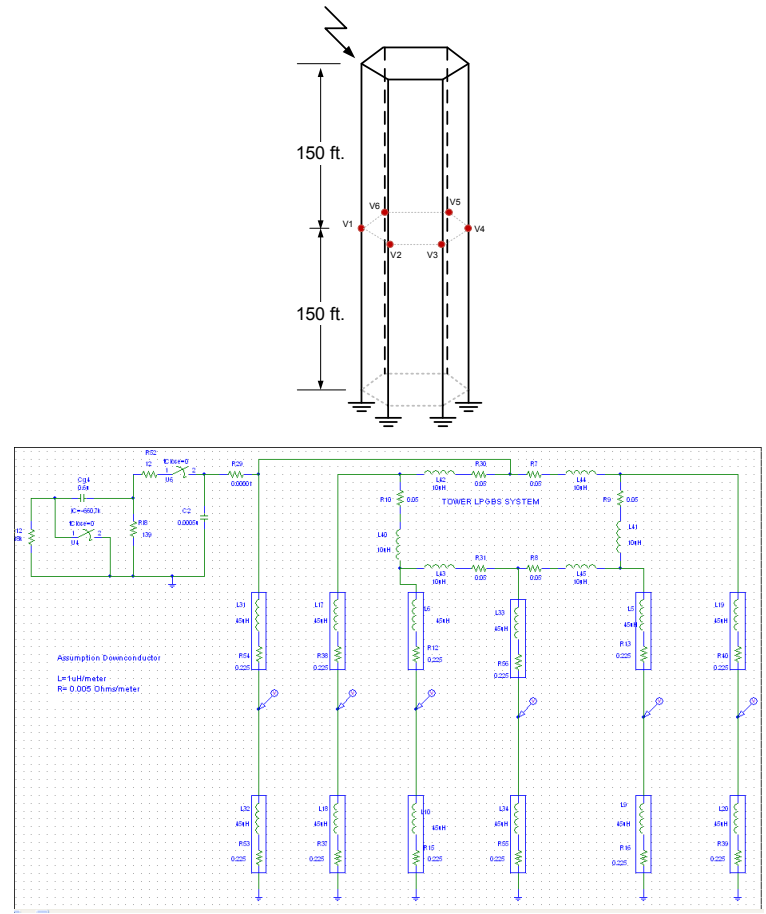

Figure 9. PSpice Lightning Protection Model for Hexagon ATCT without Equalization Ring

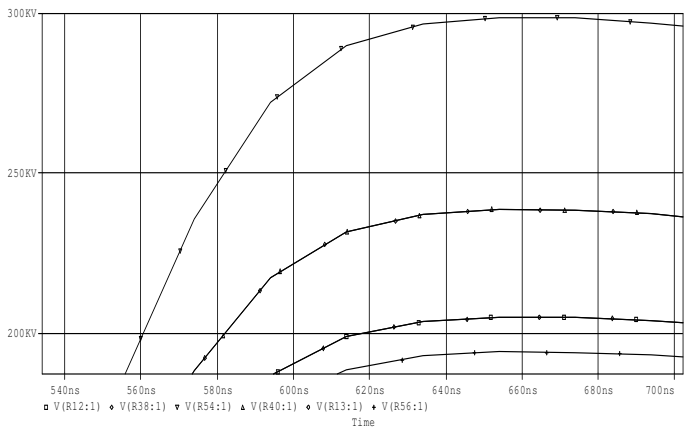

Figure 10. Lightning Protection Downconductor without an Equalization Ring, Maximum Peak Voltage Difference $=104 \mathrm{kV}$

By adding one equalization ring at the middle part of the downconductors (Figures 11 and 12), the maximum voltage differential at the midpoint of the ATCT is reduced from 104 $\mathrm{kV}$ to $28 \mathrm{kV}$, a $73 \%$ performance improvement.
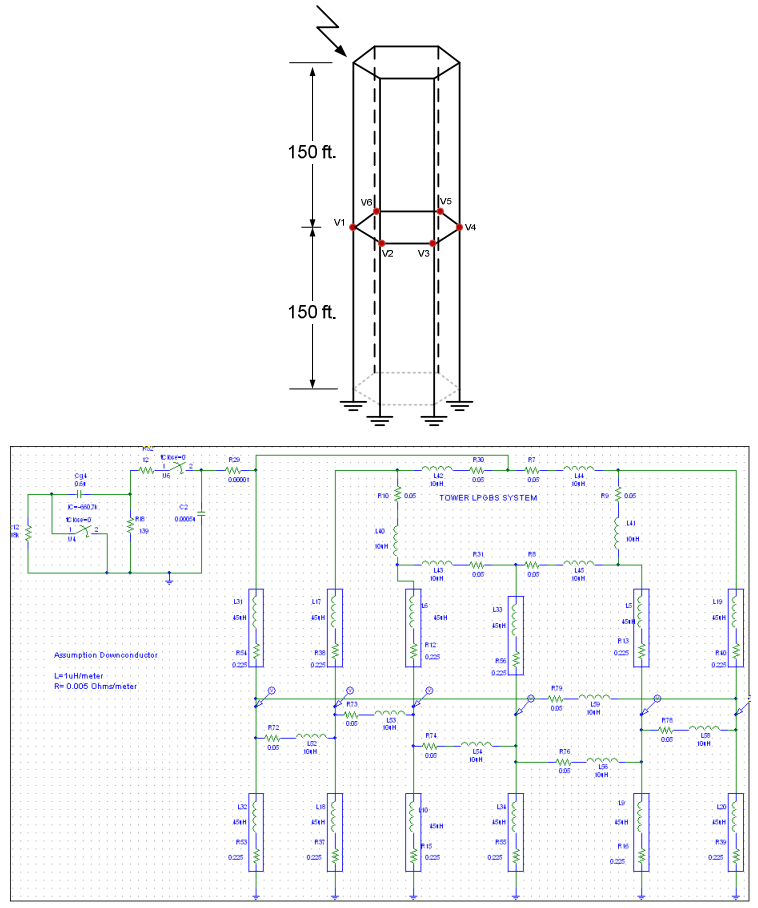

Figure 11. PSpice Lightning Protection Model for Hexagon ATCT with Equalization Ring

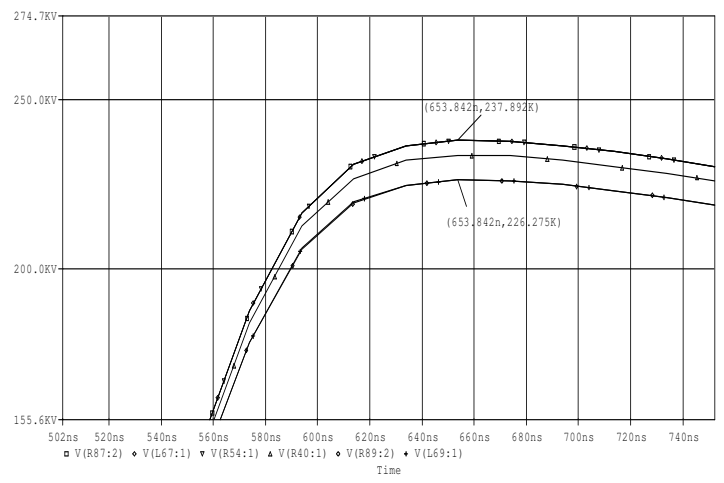

Figure 12. Lightning Protection Downconductor with an Equalization Ring, Maximum Peak Voltage Difference $=28 \mathrm{kV}$

Note on model limitation: The analysis of transient voltages as a result of simulation processes with models accessible in the program shows that PSpice program is a convenient simulation tool, although this model does not take into account other essential phenomena such as skin effect, corona effects, and other electromagnetic phenomena during transient states. Therefore, this is only a simplified model of the problem under analysis. This Pspice simulation does not take in consideration the electromagnetic effects cause by shape, the bending radius, and bonding transitions of conductors that is done at installation. However, a deeper analysis is being performed to represent a more accurate model than the one presented in this concept paper. 


\section{CONCLUSIONS}

This paper presents a full-protection geometry-based approach lightning protection scheme for the installation of downconductors on an ATCT and compares it with two other standards, NFPA-780 and FAA-STD-019e. It demonstrates that increasing the number of downconductors for a particular building height reduces the overall impedance of the structure. The installation of equalization rings reduces the voltage difference at particular heights, improving the balanced configuration of the lightning protection system. In practice, the geometry-based approach and balanced placement of downconductors, combined with the number of downconductors and equalization rings, provides a higher level of protection compared to general practices. The combined methods reduce the risk of accidents to the surrounding structure as well as people and equipment inside the structure. The result is continuity of air traffic operation.

\section{REFERENCES}

[1] S. Ait-Amar and G. Berger, "Attractive Radius of Elevated Building" in Proceeding 28th International Conference on Lightning Protection, Kanazawa, Japan, 2006, pp. 602 -607.

[2] "Tasting Edge Effects" American Journal of Physics, Volume 75, Issue 2, pp. 148- 150, 2007.

[3] FAA-STD-019e, "Lightning and Surge Protection, Grounding, Bonding and Shielding Requirements for Facilities and Electronic Equipment" Federal Aviation Administration, 2005.

[4] Standard for the Installation of Lightning Protection Systems, NFPA Std. 780, 2011, NFPA 780 ed.

[5] M. S. Kamarudin, E. Sulaiman, Md Zarafi Ahmad, S. A. Zulkifli and A. F. Othman, "Impulse Generator and Lightning Characteristics Simulation using Orcad PSpice Software" in Proceedings of $2^{\text {nd }}$ Engineering Conference on Sustainable Engineering Infrastructure Development and Management, 2008. 